\title{
ANTLER DEVELOPMENT IN TROPICAL SAMBAR (Cervus unicolor) STAGS
}

\author{
Gono Semiadi'
}

\begin{abstract}
Antler development from captive sambar (Cervus unicolor) stags under temperate conditions monitored for six years (1989-1994). Peak time of adult stags ( $\geq 3$ years of age) in hard antler was from May to October and in young stags ( $<3$ years of age) was from July to October. In general, stags in hard antler can be found all year round and antlers were cast annually. Adult stags had their mean date of velvet antler stripping 31 days earlier than young stags and the mean date of antler casting being 39 days later. Young sambar stags tend to match their hard antler conditions within the majority of adult stags in hard antler period. Hard antler weight, antler length and beam circumference were heavier, longer and larger in adult stags than from young stags. Rutting behaviour from a group of stags which did not have any access to hind showed a weak hierarchical structure. Fighting and challenging each other during this time occured only due to feed competition. Testicle drop occured at 127 days ( $\mathrm{SE}=7.69$ days) or at a body weight of $46.1 \mathrm{~kg}$ ( $\mathrm{SE}=1.69$ days). In conclusion sambar stags under temperate conditions are still showing their inherit tropical pattern and there was a tendency of synchronization on their hard antler cycle, although it was weak.
\end{abstract}

(Keywords: Sambar deer, Cervus unicolor, Antlers, Cast.)

Buletin Pelernakan 19: 184-190, 1995

'Puslitbang Biologi-LIPI, JI. H. Juanda 18, Bogor 16I22 


\section{INTISARI}

Pertumbuhan ranggah dari rusa sambar (Cervus unicolor) yang ditangkarkan di daerah temperate diamati selama 6 tahun (1989-1994). Masa tertinggi pada pejantan dewasa ( $\geq 3$ tahun) dengan ranggah keras adalah dari bulan Mei hingga Oktober dan pada pejantan muda ( $<3$ talıun) adalah dari bulan Juli hingga Oktober. Secara umum pejantan dalam ranggah keras dapat dijumpai setiap saat dalam setahun. Luruh ranggah terjadi setiap tahun. Rerata tanggal ranggah velvet mengelupas pada pejantan dewasa adalah 31 hari lebih awal dari pejantan muda, sedangkan rerata tanggal luruh ranggah adalah 39 hari lebih lambat. Pejantan muda cenderung untuk mengikuti pola perkembangan ranggah kerasnya dengan keadaan pola ranggah keras pada pejantan dewasa. Berat, panjang dan diameter ranggah keras pada pejantan dewasa adalah lebih tinggi dibandingkan dengan ranggah yang berasal dari pejantan muda. Perilaku kawin pada pejantan yang terpisah dari hewan betina menunjukkan adanya susunan struktur sosial yang agak lemah. Perkelahian dan saling menantang pada saat tersebut terjadi hanya karena perselisihan pakan. Turunnya testis ke dalam kantung scrotum terjadi pada unur 127 hari ( $\mathrm{SE}=7,69$ hari) atau pada berat 46,1 $\mathrm{kg}(\mathrm{SE}=1,69$ hari). Dapat disimpulkan bahwa rusa jantan sambar yang hidup di daerah temperate masih menunjukkan sifat nenek moyangnya yang berada di daerah tropika dan ada kecenderungan sinkronisasi dalam hal perkembangan ranggah keras, tetapi keadaannya tidak begitu kuat.

(Kata kunci : Rusa sambar, Cervus unicolor, Ranggah, Luruh.)

\section{Introduction}

Comprehensive studies on the antler developments of tropical deer are sparse, with most of works being conducted in non-tropical environments (Louden and Curlewis, 1988; Mylrea, 1992; van Mourik, 1985). Studies under their tropical habitats were mostly obtained from the wild observations (Mishra, 1982; Mathur, 1991). Sambar deer (Cervus unicolor) in New Zealand originated from Sri Lanka and first liberated in 1875 (Harris, 1971). The present of a small sambar herd in captivity was enabling to evaluate their biology. Thus, the development of antlers and their relation to rutting behaviour can aiso be observed. The present study was the summation of continues monitoring for six years (1989-1994) on antler developments of captive sambar stags in New Zealand.

\section{Materials and Methods}

\section{Location}

The farm was located at Flock House Agricultural Centre, New Zealand Pastoral Agricultural Institute, Bulls, on the west coast of the North Island (lat. $40^{\circ} 14^{\prime}$ $\mathrm{S}$ and long. $\left.175^{\circ} 16^{\prime} \mathrm{E}\right)$. Average annual rainfall is $875 \mathrm{~mm}$ with a dry period from January to March (summer), and strong westerly winds during October and November (spring). The mean monthly temperature ranges from $9^{\circ} \mathrm{C}$ to $20^{\circ} \mathrm{C}$, with the longest day of frost during winter being saml

conc

year

stag:

0.85

oper

com

set

inclt

The

natu

winc

$\operatorname{imp}$

losse

were

fluct

unin

irrig

on $\mathrm{I}$

autu

Sept

with

betw

temp

yard

(dre:

mati

were of $\mathrm{cs}$ easy

1992

grou

stag

your

reacl

sepa.

Grot

hind: 
8 days (1988-1992).

\section{Animals and management}

Observations on semi-domesticated sambar stags running with adult hinds were conducted in two groups (A and B), for five years (1990-1994). Group A comprised two stags and six hinds, and were set stocked on 0.85 ha of pasture, with access to 0.1 ha of open pampas (Cortaderia sp.). Group B comprised six stags and 17 hinds, and were set stocked on 2.4 ha of pasture, which included 0.1 ha of pine trees (Pinus radiata). The pampas and pine trees functioned as natural shelter, particularly against westerly winds. Some animals from group B were imported from Australia in 1990. Subsequent losses due to death, culling and calf born were resulted in the number of animals to be fluctuated in concurrent year.

The pasture were considered as unimproved pasture, to which fertilizer and irrigation never been applied and no control on pasture mass was undertaken. From late autumn to early spring (mid May - mid September) all animals were supplemented with maize, lucerne hay of meadow hay between $0.50-0.75 \mathrm{~kg} / \mathrm{head} /$ day.

Because of the aggressiveness and temperamental nature of the animals, no yarding, handling or health management (drenching, vaccination) was applied. All mating occured naturally and hard antlers were never cut. Within $24 \mathrm{~h}$ after birth, $95 \%$ of calves were snatched and hand reared for easy handling and research purposes. In May 1992, all stags ( $\geq 2$ years of age) from both groups were removed, leaving only one adult stag in each group. In September 1993, as young stags (18 months of age) from group B reached their first hard antlers, they were separated into two subgroups, B1 and B2. Group B1 consisted one adult stag and six hinds, and occupied their original paddock, and group B2 consisted two young stags and four hinds occupied an area of 0.8 ha paddock without any shelter provided, adjacent to the group B1 paddock.

In addition to the semi-domesticated stags group, observations were also made on mixed-age paddock raised hand reared stags (Group $\mathrm{C}, \mathrm{n}=9$ ) where they had no access to any hind during the period of observations. They were put in 0.7 ha paddock with 0.04 ha pampas area, adjacent to group B1 paddock. Velvet antlers were cut as they reached approximately $70-75 \%$ of antler growth. Some data from indoor animals were also included when become available.

\section{Data collection}

Paddocks were visited regularly once a week and intensify to every 1-2 days as the peak calving approaches and checked for the present of a new calf (Semiadi $e t$ $a l ., 1994)$, when at the same time the antler conditions of stags were also noted. Date of antler casting, period of velvet antler growth and the period of time stags were in hard antler were calculated from the antler data. Date of velvet stripping was recorded when one of the antlers showed pronounced velvet stripping. Date of antler casting was recorded as the average of the two sides. Cast antlers were collected and antler length (length of beam) was measured from the base of the coronet to the farthest tip of the beam, and beam circumference was measured approximately $5 \mathrm{~cm}$ above the brow tine, using a flexible polypropylene tape. Similar obervations were also made on hand reared sambar stags and any aspects of male reproductive development were noted. 


\section{Results and Discussion}

\section{Results}

Antler cycles. Peak number of adult stags in hard antler occured from June to October, with August as the time when all adult stags were in hard antler. Peak number of young stags in hard antler was a montl later than from the adult stags, from May to October. There was a tendency of younger animals to adjust their hard antler period within the pattern of majority adult stags. However, in general, stags in hard antler can be found all year round with the antlers were cast annually. One young stag from group B2 had his second year velvet antler growth for 90 days only and retaining its hard antler for 25 days only.

Antler development. Data of antler development in young and adult stags were presented in Table 1. Mean date of velvet stripping in adult stags was 31 days earlier than from young stags, with the mean date of antler casting being 39 days later in adult stags than of the young stags. Intercast between the two antlers was slighty longer in young animals, as well as the period of antler growth. Hard antler weight of adult stags was twice as heavy as the young stags, with the antler length and circumference being longer and larger in adult stags than in young stags.

Two young stags had their first year hard antler length for $5.6 \mathrm{~cm}$ ( $\mathrm{SE}=0.21$ ), half the length of the majority first year hard antler $(10.9 \mathrm{~cm}, \mathrm{SE}=0.30, \mathrm{n}=4)$. One young semi-domesticated stag had his first year hard antler length approximately $25 \mathrm{~cm}$ long.

Rutting behaviour. Observations from group $\mathrm{C}$, where the stags did not have any access to hind, indicated a weak hierarchical structure during the hard antler period. Aggressiveness among rutting stags (adult and young), shown by fighting and challenging each other, was almost non existence in their daily activities. Their daily activities were spent mostly by lying and grazing, with one or two stags, presumably the dominant ones, were wallowing in a water through and tried to spray their head while urination. In several occasions, when a young stag (9 months of age) was urinating, two to three stags in hard antlers were rushing toward the young stag and deliberately wetting their nose, mouth and head regions with the young stag urine. Such aggressive behaviour would appear only for feed competition, when feed supplement was given, due to a low winter feed availability (June - mid September). At that time, the dominant stag (s) would take an initiative in defending the feoding site and at several occasions fighting occured. However, all slags displayed their distinctive rutting behaviour by rubbing their hard antlers against fence posts. The development of testicle dropped into scrotum was noticed in three stags, with the mean age at 127 days (SE $=7.68$ days) and at a body weight of $46.1 \mathrm{~kg}(\mathrm{SE}=1.69$ $\mathrm{kg})$.

\section{Discussion}

Stags in hard antler were found all year round in the present study was similar to what been found in their natural habitat (Kitchener, 1961). The peak number of adult stags in hard antler in the present study was similar from a limited observation conducted in the wild in New Zealand, being July to August (Rudd, 1978). In Myanmar, a peak period of stags in hard antler was from May to Jully (Thom, 1937). Thus, it is likely that although the present sambar deer are 
TABLE 1. DATE OF ANTLER DEVELOPMENT (MEAN, SE) AND ANTLER DIMENSIONS (MEAN, SE) OF CAPTIVE ADULT ( $\geq 3$ YEARS OF AGE) AND YOUNG ( $\geq$ YEARS OF AGE) SAMBAR STAGS UNDER NEW ZEALAND CONDITIONS, DURING 1989-1994 ( $\mathrm{N}=$ NUMBER OF OBSERVATION)

\begin{tabular}{|c|c|c|c|c|}
\hline & Adult & $n$ & Young & $n$ \\
\hline Mean date of velvet stripping' & $20 \wedge$ pril (7.5) & 18 & 21 May (10.5) & 21 \\
\hline Mean date of antler casting ${ }^{2}$ & $\begin{array}{l}18 \text { October } \\
(19.0)\end{array}$ & 10 & $\begin{array}{l}10 \text { August } \\
(31.3)\end{array}$ & 10 \\
\hline $\begin{array}{l}\text { Period of velvet antler growilı } \\
\text { (days) }\end{array}$ & $135(5.16)$ & 16 & $141(21.3)$ & 6 \\
\hline $\begin{array}{l}\text { Mean length of time in hard } \\
\text { antlers (days) }\end{array}$ & $222(12.6)$ & 10 & $218(23.7)^{3}$ & 10 \\
\hline $\begin{array}{l}\text { Intercast between the two } \\
\text { antlers (diays) }\end{array}$ & $1.9(0.28)$ & 10 & $2.2(0.25)$ & 10 \\
\hline $\begin{array}{l}\text { Age at the first year hard } \\
\text { antler (days) }\end{array}$ & $\cdots$ & & $468 \cdot(20.4)$ & 12 \\
\hline \multicolumn{5}{|l|}{ Hard antler: } \\
\hline length $(\mathrm{cm})$ & $58.1(1.99)$ & 12 & $39.9(1.35)^{3}$ & 8 \\
\hline circumference $(\mathrm{cm})$ & $13.0(0.34)$ & 12 & $10.1(0.30)^{3}$ & 8 \\
\hline weight (g) & $1047(72.57)$ & 12 & $419.7(26.80)^{3}$ & 8 \\
\hline
\end{tabular}

' culculated from one side

1 calculated as the menu of both sides

'enleulnted from the second yenr hard antler

showing their inherit antler cycle under tropical habitat, but in New Zealand they sem to also have established their own peak pattern. Wider spread of stags in hard antler a compared to red stags is due to a wider spread of calving in sambar deer (Semiadi, 1995).
Kitchener (1961) reported that the length of first year hard antler of a young male sambar in Malaysia was between 25 to $31 \mathrm{~cm}$ and being achieved at 2 years of age. This is twice to three times longer than the average antler length and approximately at 160 days older of the present sambar deer. 
Such big differences could be due to the different subspecies and environemtnal factors. Variation on the length of firs year hard antler occurred, but any length under 5 $\mathrm{cm}$ long and above $25 \mathrm{~cm}$ would be exception.

The present mean date of antler developments in both young and aduit stags were slightly varied from the previous observations (Semiadi et al., 1994) indicates that calving time and management lad an effect. Relatively longer time on antler cast in young animals showed that within the younger generation there is a mechanism in attemting to have the next antler growth within the majority adult stags antler growth. What causes of a short period in antler development in one young stag is unknown. Stress conditions seem can caused interruption in the antler development, since the occurrence of such peculiar antler development was during the period when all semi-domesticated animals were need to be darted using live ammunition rifle for tuberculosis test. During that period, the sound of the gun was prominent to cause the animals under stressful conditions.

Rutting behaviour in the present sambar stags is slightly different with that sambar stags when stay together with hinds (Semiadi et al., 1994). It seems that aggressive behaviour in sambar stags is more in gaining control toward the hinds rather than as a "territorial leader" in every aspects. Semiadi et al. (1994) showed that up to a certain degree, dominant sambar stag was still tolerated for the present of the rival stag nearby the protected hinds (harem), and even playing together. These rutting behaviour are different with that observed in red stags.

From the present wtudy it can be concluded that sambar stags under temperate conditions are still showing their inherit tropical patterm and there was a tendency to synchronize their hard antler cycle, although it was weak. Further study to understand the synchronization mechanism in sambar stags during in hard antlers is needed in particular for the benefit on the development of tropical deer farm.

\section{Acknowledgements}

Prof. T.N. Barry from Massey University and Dr. P.D. Muir are thanked for their guidance during the study.

\section{References}

Harris, L.H. 1971. Notes on the introduction and history of sambar deer in New Zenland. New Zenland Wildlife 35: 33- 42.

Kitchener, 11.J. 1961. The sambur deer Cervus turicolor equinus. Mulayan Nature J. 15: $52-61$.

Louton, A.S.I. and J.D. Curlewis. 1988. Cycies of uniler and testicular growth in an ascasonal Iropicul deer (Avis axis). J. of Reproduction and Fertility 83: 729-738.

Mathur, V.B. 1991. The esological interaction between lunhitnt composition, habitat quality and abundance of some wild ungulates in India. PhD thesis. University of Oxford. Unital Kinglum. $240 \mathrm{pp}$.

Mishrn, H.R. 1982. The ceology and belunviour of chital (Avis axis) in the Royal Chitawan Nutional Park, Nepal, (with comparative studies of log deer (Axis porcinus), sambar (Cervus unicolor) and barking deer (Muntiacusmuntjak). PhD thesis. University of Edinburgh. Scotland. $224 \mathrm{pp}$.

Mylren, G.E. 1992. Natural and artificinl breeding of farmed chital decr (Avis avis) in Australiat. PliD thesis. $266 \mathrm{pp}$. University of Sydncy, Sydney, Austrulin.

Rudd, J. 1978. The antler growth pattern in the Bay of Plenty sumbar herd. New Zenland Wildlife 7: 33-35.

Scmiadi, G., P.D. Muir and T.N. Burry. 1994. General biology of sambar deer (Cervus unicolor) in capacity. New Zenland J. of Agricultural Rescarclı 37: 79-85. 
Semiadi, G. 1995. Reproductive performance of sambar (Cervus unicolor) hinds. Molin Veteriner. Subınitted,

Thom, W.S. 1937. The Malnyun or Burmese sambar (Rusa unicolor equinus). J. Bombay Natural History 39: 309-319. van Mourik, S.C. 1985. Behnvieur and physiology of furmed rusa deer (Cervus rusa timorensis). PhD thesis. University of Melbourne. Victorin. 